\title{
CASTING METALS IN DENTISTRY: PAST - PRESENT - FUTURE
}

\author{
K. ASGAR \\ Department of Biomaterials, School of Dentistry, University of Michigan, Ann Arbor, Michigan 48109
}

\section{Adv Dent Res 2(1):33-43, August, 1988}

\section{ABSTRACT}

$\mathbf{T}$ his article deals mainly with the development of dental casting techniques and formulation of the different groups of alloys used in the fabrication of ceramo-metal restorations.

It is recognized that in order for the quality of dental cast restorations to be improved, having alloys with the proper composition is not enough. Biocompatibility, good mechanical and physical properties, longevity of the restoration, compatibility with porcelain, and a simple manipulative technique are as important. Researchers have contributed to different aspects of dental castings and have made cast restorations what they are today. Unfortunately, much of the original basic research has been overlooked by present investigators, who have duplicated studies conducted in the past without realizing that the study had already been performed and the research had been published. The main reason for this is that abstracts of articles published prior to 1975 are not available through a library computer-search system. To obtain copies of articles published prior to 1975, one has to search the literature to know where they were published. This article provides references for much of the past work in this area. Also, dental libraries do not carry copies of U.S. patents. This places the majority of researchers located at dental schools at a disadvantage. They are not familiar with what the patents claim, what is taught, and why certain elements are added or eliminated from alloys and investment materials. This article also provides the numbers of many U.S. patents. By having the patent number, one can obtain the text of the patent from the U.S. Patent Office in Washington, DC.

Since esthetics plays an important role in today's society, emphasis will be given only to alloys designed for fabrication of ceramo-metal restorations. Many ceramo-metal alloys are available today, and they are classified differently by different individuals. In this article, classification will be based on the major components of these alloys, as well as on a chronological introduction of one group leading to the development of the next group. Based on this, one can classify these alloys into six major groups. Chemical composition, properties, and the developers of these alloys, along with their U.S. patents, are given.

Recently, two types of all-ceramic restorations have been introduced. The main advantage of the all-ceramic restoration is its superior esthetic quality compared with that of ceramo-metal restorations. Their main disadvantages are low strength and ductility. Their strength, however, is sufficient for single-unit restorations, but not for bridgework. The use of titanium for dental restorations has also been studied, and it has been found to be suitable.

Future Studies - Future work should be devoted to the following: (1) the development of stronger and more ductile ceramic materials: (2) further study of the promising palladium alloys from the noble metal group and titanium alloys from the base metal group; (3) the development of easier and less-time-consuming techniques for the fabrication of dental appliances; (4) the development of a powder technique rather than a cast technique for future fabrication methods; and (5) the development of new laboratory equipment, e.g., a single sintering oven capable of sintering both ceramic and metallic particles, which would be accepted if the powder technique is developed.

\section{INTRODUCTION}

Casting metals by the lost-wax process has been recognized in industry and the arts for many years. No record exists to indicate exactly when and where

Presented at the International State-of-the-Art Conference on Restorative Dental Materials, September 8-10, 1986, National Institute of Dental Research this type of casting procedure was first developed. All that is known is that somewhere along the line - it may have been in ancient Egypt or in ancient China - someone conceived of the idea of making a wax replica of an item to be cast, surrounding this replica with an investment material, letting the investment harden, then melting and burning out the wax, thus producing a mold having a highly intricate 
and accurate cavity. The next steps were melting the metal and pouring it into the cavity.

It has long been the dentist's desire, however, to be able to produce a restoration in the laboratory and place it in the patient's mouth in a relatively short time. This desire probably arose as a result of the early method of placing gold foil fillings. It was a generally accepted practice to work continuously on the patient until all cavities were prepared. This operation often required two or three days. The cavities were then filled temporarily, and the foil was placed at the next appointment.

In the literature, credit is given to Dr. Swasey (1890), who introduced a technique where a solid gold inlay could be prepared. In his technique, the gold foil was first adapted to the shape and contour of the tooth, then removed, invested, and filled with 20-karat gold. Wax was used for making gold inlays for the first time by Martin (1891). According to Martin's technique, there was no need to use a foil liner. He filled the cavity with wax, removed it after hardening, invested it, burned it out, and then poured the molten gold into the mold formed in the investment.

A few years later, Dr. Philbrook (1896) introduced a pressure-casting method of producing gold inlays. His technique was essentially the same as that used today. In his technique, the wax pattern was formed directly in the mouth, mounted on a sprue pin, and invested in a metal ring, with plaster of Paris and silex used as an investment medium. The metal ring was placed in an oven for wax elimination. Finally, the alloy was melted in a crucible formed in the investment, and cast by means of air pressure. At the time, the profession failed to realize the significance of Philbrook's contribution. It is Philbrook whose name should be associated with the method of casting dental castings under pressure. About 10 years later, Dr. Taggart (1907) presented a paper before the New York Odontological Group, in which he discussed his casting technique and machine. Taggart's success was mostly due to his improved casting machine, since his casting technique was not original; the idea of using wax to form the pattern was that of Martin (1891), and using pressure to cast the alloy was that of Philbrook (1896). Whether Taggart or Philbrook or Martin should be called the father of today's dental casting procedure is debatable.

Castings made using Taggart's casting machine and his investment were generally too small and did not fit the cavities properly. Van Horn (1910) suggested and promoted the idea of thermally expanding wax patterns prior to investing. During the decade of the 1920 's, the commercial possibilities of Van Horn's technique were suddenly appreciated, and a large number of new casting procedures were introduced, resulting in the marketing of much new equipment without much improvement in the fit of castings. The development of cristobalite investment by Coleman and Weinstein in 1929, who obtained a U.S. patent a few years later (1933), as well as the introduction of the hygroscopic technique (Scheu, 1932), were responsible for the greatest improvement in the fit of dental castings.

In general, just having a good dental alloy is not sufficient to improve dental castings. Besides a properly formulated and carefully manufactured dental alloy, one needs a good investment, the proper equipment, and well-defined, easily usable technique. The high level of accuracy of the fit that dental castings of today have reached is the result of improvements made in all of these areas - namely, alloy, investment, equipment, and casting technique.

As cristobalite-containing investments became available on the market, many researchers - such as Volland and Paffenbarger (1932), Coy (1933), Phillips (1933), and Sweeney (1933) - published articles showing the results of their closely fitted castings. In the meantime, the desirability of attempting to obtain a significant amount of compensation by means of wax expansion was successfully challenged by Maves (1932) and later by Lasater (1940), when they showed that all wax patterns distorted when heated. As a result of these studies, a casting technique employing investments containing cristobalite (which compensates for a major portion of the shrinkage of alloy and wax pattern by thermal expansion) became popular. In later years, many more investigators published the results of their studies using investments containing cristobalite. Today, such investments are called "thermal-expanding investments" and are more popular than their counterparts, which are low-heat or hygroscopic investments.

From the time that Dr. Scheu introduced his hygroscopic technique, various aspects of hygroscopic investments were studied by many individuals, and some theories were postulated. Researchers such as Degni (1946), Skinner and Degni (1957), Docking et al. (1948 a-c, 1949), and Peyton and his colleagues [Landgren (1950); Delgado (1953); Asgar (1954, 1958); Jorgensen (1956); Fusayama (1957); Dickson et al. (1955); and Ryge and Fairhurst (1956)] studied various aspects of the hygroscopic expansion of investments, and many theories were set forth. Finally, Mahler and Ady (1960), in their classic paper, showed that the hygroscopic expansion of dental investments is a continuation of setting expansion and proposed the theory which is accepted today. Since the hygroscopic technique is a more complicated technique, compared with the thermal expansion technique, many researchers have modified and developed new casting techniques based on the hygroscopic expansion of the investment. To name a few, these include Scheu (1933), Crawford (1940), Hollenback (1943, 1948), Smyd (1948), Asgar et al. (1955), and Sturdevant (1959).

As mentioned earlier, the quality of dental castings would not be where it is today if a better understanding of the basic nature of dental castings and improvement in investments and alloys had not been accomplished. Much work in the various aspects of dental casting techniques - such as the effect of mold 
and metal temperature on the fit of castings, castability of the various alloys, choice of sprue as well as its size and location, and the effects of various types of dental wax on the resultant casting - has been reported. It is almost impossible to cite those articles in such a short review; therefore, it will not be attempted.

In the 1950's, researchers were looking for further improvements in crown and bridge prosthodontics. Their main concern was to improve esthetics. Credit is usually given to Dr. Abraham Weinstein, who was the first to produce a commercially successful dental gold alloy and porcelain composite and who obtained two U.S. patents (Weinstein et al., $1962 \mathrm{a}, \mathrm{b}$ ). The J.F. Jelenko Company and the J. Aderer Company were the first dental companies to introduce a gold-based alloy on which porcelain could be baked. In the meantime, the Whip-Mix Corporation developed a phosphate-bonded investment in which the high-fusing alloys of Jelenko and Aderer could be cast successfully with the use of existing casting techniques and equipment. With the introduction of these new materials, it was possible for porcelain to be baked successfully over gold-based alloys, and, along with the development of high-speed hand-pieces, the direction of dental practice changed.

Today, relatively few full-metal-cast restorations are made. The public is demanding not only well-functioning restorations, but also those which cosmetically match the natural dentition. Alloys used today in the fabrication of porcelain-to-metal restorations have been classified differently by different individuals. One method of classification is based on major components of the restorations as well as on a chronological introduction of one group leading to the development of the next group. Based on these points, one could classify the restorations into six groups, as shown in the Table.

As mentioned earlier, the first group of alloys was developed in the late 1950's. Compared with the other groups, alloys of this group contain the highest percentage of noble metal - the largest portion of which is gold (84-88\%). The other elements in these alloys are platinum (4-10\%) and palladium (5-7\%), with 2 $3 \%$ base metals. In general, these alloys are weak, and their sag resistance is lower than that of the other alloys in other groups. They cast and solder easily and have a yellow color, which is of great help when restorations with light shades are being made. Because of the high gold content, the cost of this group of alloys is relatively high.

Joseph Tuccillo $(1976 a, b)$, while working with the Jelenko Company, obtained a U.S. patent for a second group of alloys. When the composition of these alloys was compared with those of the first group, it showed that platinum, which is the most expensive element in group I alloys, was completely eliminated. The percentage of gold was reduced from $84-87 \%$ to $51-54 \%$, and the palladium concentration had been increased from $5-7 \%$ to $26-31 \%$, so that the alloys of this group contained $80 \%$ noble metal, while the total noble metal content of group I was $97-98 \%$. This group of alloys contained a considerable amount of silver (14-16\%). The mechanical properties of this group of alloys were much improved compared with those of the first group. They have higher strength, bridges made of these alloys sag less, they cast well and solder easily. Also, they are much more economical. Two main disadvantages of alloys in this group are: occasional greening of the porcelain due to the presence of silver, and the fact that the color of the alloy is gray, even though the alloys contain about $50 \%$ gold. With the gray color of the alloy, it is more difficult to produce a light shade on the porcelain. It is one of the characteristics of palladium to dominate its alloys with a grayish color. For example, an alloy containing $15 \%$ palladium and $85 \%$ gold will have the color of palladium.

Clyde Ingersoll (1975 a-d) of the Williams Gold Refining Company obtained a U.S. patent for his newly developed alloy. This group of alloys contains 53-60\% palladium and $30-37 \%$ silver, with the balance being base metals. The mechanical properties of this group of alloys are good, and they cast and solder easily.

TABLE

COMPOSITION OF PORCELAIN-TO-METAL ALLOYS

\begin{tabular}{|c|c|c|c|c|c|}
\hline Group 1 & Group 2 & Group 3 & Group 4 & Group 5 & Group 6 \\
\hline $96 \%-98 \%$ Noble Metal & $80 \%$ Noble Metal & Pd-base Alloys & $90 \%$ Noble Metal & $60-82 \% \mathrm{NI}$ & $55-64 \% \mathrm{Co}$ \\
\hline $84-86 \% \mathrm{Au}$ & $51-54 \% \mathrm{Au}$ & No $\mathrm{Au}$ or $\mathrm{Pt}$ & $45-52 \% \mathrm{Au}$ & $20-11 \% \mathrm{Cr}$ & $25-34 \% \mathrm{Cr}$ \\
\hline $4-10 \% \mathrm{Pt}$ & No Pt & A) $\begin{array}{l}53-60 \% \mathrm{Pd} \\
30-37 \% \mathrm{Ag}\end{array}$ & $38-45 \% \mathrm{Pd}$ & $0-9 \%$ Mo & $2-9 \% \mathrm{Mo}$ \\
\hline $5-7 \% \mathrm{Pd}$ & $26-31 \% \mathrm{Pd}$ & $10 \%$ Base Metals & No Ag & $0-2 \% \mathrm{Be}$ & \\
\hline 2- $3 \%$ Base Metals & $14-16 \% \mathrm{Ag}$ & $\begin{array}{c}\text { B) } 79-88 \% \mathrm{Pd} \\
4-5 \% \mathrm{Co} \\
\text { Bal. Base Metals } \\
\text { C) } 79.81 \% \mathrm{Pd} \\
10 \% \mathrm{Cu} \\
9 \% \mathrm{Ga}\end{array}$ & & & \\
\hline
\end{tabular}


The cost of this group of alloys is lower than that of any other noble metal alloys on the market. The coefficient of thermal expansion of this group of alloys is higher than those of groups I and II. Therefore, for optimum bond strength, they should be used with higher-shrinkage porcelains, and they are not compatible with all porcelains on the market. They contain a much higher percentage of silver compared with alloys in group II, and therefore, the chance of obtaining a green color on the porcelain increases considerably. Today there is a procedure to prevent greening of porcelain in silver-containing porcelain alloys. When this procedure is followed, the greening problem is eliminated.

A few years later, Paul Cascone (1978) of the Jelenko Company obtained a U.S. patent for his alloy, which did not contain any platinum or silver. Alloys of this group may contain $45-52 \%$ gold and $38-45 \%$ palladium, such that $90 \%$ of the alloy is noble metal and the balance is base metals. Mechanical properties, castability, solderability, and dimensional accuracy of this group are better than those of other noble metal alloys. The coefficient of thermal expansion of this type of alloy is slightly lower than that of the other groups of alloys. Like the palladium-silver group of alloys, this group is not compatible with all of the porcelains on the market. Optimum porcelain-alloy bonding is obtained with porcelains that also have a lower coefficient of thermal contraction. The main advantage of this group of alloys over those in group II is that these alloys do not contain any silver, and the chance of obtaining a green line on the porcelain does not exist. Later, Cascone $(1985 \mathrm{a}, \mathrm{b})$ obtained another U.S. patent for gold-palladium alloys containing no silver. The main advantages of the second group of alloys are that they have a higher coefficient of expansion (making them more compatible with various porcelains) and that they contain a lower percentage of gold (making them more economical).

Boyajian (1981), while working on his Ph.D. at the University of Virginia, developed the first palladiumbased alloy containing no gold, platinum, or silver. With the addition of $5 \%$ cobalt and the proper percentages of tin and indium, he managed to raise the strength as well as the coefficient of thermal expansion of the alloy to be compatible with those of existing porcelains. Later, he obtained two U.S. patents for his formula, in which he limited the cobalt content of the alloy to $7.5 \%$. Palladium alloys containing more than $7.5 \%$ cobalt become electromagnetic. Studies have not been able to detect whether magnetic or nonmagnetic alloys are more beneficial in practical cases. However, the magnetic alloys do set off the security check mechanisms located in airports.

Cascone (1985) later introduced a palladium-based alloy containing only $4 \%$ cobalt, which makes it nonmagnetic. The main advantage of this alloy was that by properly balancing its ingredients and by special manufacturing procedures, it was possible for a single-phase, stable Pd-Co alloy to be formed.
Schaffer (1983) of the J.M. Ney Company obtained a U.S. patent for the introduction of a palladiumbased alloy for porcelain-to-metal restorations containing $10 \%$ copper. Prior to Schaffer's palladiumcopper alloy, those in the field believed that the presence of copper in the alloy would cause discoloration of the porcelain. This belief was based on some unpublished work performed in the early 1950's, but that work had been performed on gold-based alloys and not on palladium-based ones.

An attempt was initiated prior to the 1950's to bake porcelain on nickel-based alloys. Due to the lack of a suitable porcelain, a good investment, and the proper casting technique, this was not successful. After development of the proper materials, the fabrication of the porcelain-to-metal restoration became popular in dentistry; usage of nickel-based alloys for crown and bridge prostheses increased at a very fast rate. In the late 1970 's, the price of gold increased considerably, and the use of nickel-based alloys for porcelain-tometal restorations became very popular. These alloys contain a very large percentage of nickel (60-82\%), chromium (11-20\%), molybdenum (0-9\%), and beryllium $(0-2 \%)$ by weight. Even though the beryllium content is usually about $2 \%$ by weight, on an atomic basis it becomes $12 \%$. Beryllium also has a very high vapor pressure compared with that of other elements present in nickel-based alloys. At a casting temperature of $1370^{\circ} \mathrm{C}\left(2500^{\circ} \mathrm{F}\right)$, an alloy containing only $2 \%$ by weight beryllium will have a vapor pressure 20 times higher than that of the nickel or chromium in the alloy. The vapor pressure of molybdenum, however, is very low; its vapor pressure at this casting temperature is less than $10^{-7}$ times that of beryllium. Beryllium-containing alloys cast better, and they form a stronger porcelain-to-metal bond than do those not containing beryllium. Other elements found in these alloys are aluminum, silicon, titanium, tungsten, iron, tin, gallium, and phosphorus. The mechanical properties of nickel-based alloys available on the market for porcelain-to-metal restorations vary considerably from one alloy to another. The $0.2 \%$ yield strength varies from $870 \mathrm{MPa}(120,000 \mathrm{psi})$ to $28 \mathrm{MPa}(40,000$ psi), and the elongation from 3 to $20 \%$ (Asgar, 1982). The mechanical properties of the noble metal alloys belonging to the same group do not vary to this extent. Thus, it is incorrect to generalize that base metal alloys are stronger and tougher than noble metal alloys because some are stronger and some are weaker. Properties that all nickel-based alloys share are high hardness, higher modulus of elasticity, and a somewhat higher melting temperature when compared with that of noble metal alloys.

Because of the potential health hazard of nickel and beryllium present in nickel-based alloys, some cobaltbased alloys have been introduced to the market. In general, their castability, solderability, and bond strength are not as good as those of the nickel-based alloys containing beryllium. They are harder and more technique-sensitive than are nickel-based alloys. 
Meanwhile, Sozio (1986) at the Coors Porcelain Company developed a new type of ceramic material which undergoes substantially no shrinkage when fired and obtained a U.S. patent for his discovery. In a cooperative effort, researchers at Coors and Johnson \& Johnson managed to develop a technique whereby a ceramic coping could be injected onto a unique epoxy die, forming a coping as if it were a cast metal coping. Once porcelain is applied over the ceramic coping, an all-ceramic restoration is formed.

At Corning Glass Works, Beall (1972) patented his method for developing a crystalline micro glass-ceramic material. His material exhibited good machinability, mechanical strength, and impact resistance. A year later, Grossman (1973), also of Corning, developed and patented a new formula for a castable glass-ceramic material. Articles cast from such a material exhibited even better machinability and mechanical strength, moderate thermal expansion, and good acid durability. Such a glass-ceramic is essentially tetrasilicic fluormica crystals uniformly dispersed throughout a glassy matrix. A few years later, Peter Adair (1984), a dental technician, patented the idea of forming dental appliances by casting ceramic materials. The idea was then proposed to the Corning Glass Works. Then, Corning Glass, with the cooperation of Dentsply International, modified Grossman's glass-ceramic formula and introduced a fullcast ceramic material to dentistry.

The main advantage of Coors' and Corning's ceramic materials is the esthetic quality of the restorations, which is superior when compared with that of ceramo-metal restorations. Their two main disadvantages are (1) low strength and (2) absence of ductility. Their strength is not sufficient to withstand stresses that are developed in dental bridges. Also, the cavity preparations have to be perfect-deformations due to minor undercuts in preparations would fracture the restoration during its fabrication in the dental laboratory. With ceramo-metal restorations, however, such minor deformations are no real problem. Therefore, not every dentist can successfully use full-ceramic restorations time after time.

In the area of metallic restorations, suitability of titanium alloys for dental use is being studied. Some information has been reported by Waterstrat and Giuseppetti (1985) and Rupp (1985, 1986), from the National Bureau of Standards, as well as by Greener and his colleagues (Moser et al., 1984; Taira, 1985) at Northwestern University. It seems that titanium alloys are well-suited for fabrication of dental appliances.

\section{Future STUdies}

Esthetics is important in today's society. Dentists and researchers share this concern, and they have even more demands: They insist on good mechanical and physical properties of materials as well as on reasonable longevity of the restoration. They also require that the technique of preparing such a restoration be relatively easy and that the cost not exceed that of existing materials designed for the same purpose. Full-ceramic restorations need more research to develop materials to fulfill these requirements. At the present time, neither Johnson \& Johnson's nor Dentsply's materials on the market have sufficient strength to withstand stresses induced by 3- or 4-unit bridges. Even if today's materials did have sufficient strength, the cavity preparation technique would limit its usage. Only dentists capable of preparing ideal cavity preparations could use them successfully. A single crown made of these ceramics fractures during fabrication in the laboratory if the preparation has even a very minor undercut. Making a bridge increases difficulty of preparation considerably, not only because of possible undercuts on the abutments, but also because of the nonparallel lines of draw, and because of deflection caused by the normal forces of mastication.

Ceramics of the future can be improved in many areas. They should have greater ductility, greater yield strength, and not be as technique-sensitive. Their in vivo wear properties and the durability of stain materials placed on them to achieve the desired shading should be studied; these are as yet undetermined, even for today's ceramic materials. It seems that this is a large order and that these problems will probably not be solved during the next 10 to 20 years. Are we, within the next 20 to 30 years, going to be able to replace metallic structures completely with ceramics? The answer is NO, and we will probably never be able to replace metallic restorations completely. When and if the properties of ceramics are improved considerably, they will probably replace the ceramic-metal restorations to a great extent, but will never completely replace them. Damages caused by accidents and disease will probably demand either full metallic structures or ceramic-metal combinations. In the area of partial dentures and metallic denture bases for complete denture patients, where the transfer of heat and cold for healthier tissue is important, metals will be around dental laboratories and dental offices for a long time.

In the area of research for ceramo-metal or for fullcast metal appliances, it seems that the metals of the future are palladium from the noble metal group and titanium from the base metal group. Both palladiumand titanium-based alloys, with some modifications, could be used as partial denture alloys, as well as in metal palates in complete denture cases.

Palladium, being one of the noble metals, has a very good in vivo corrosion resistance. In many respects, it resembles platinum, and on today's market it costs about 75 to $78 \%$ less than platinum. Palladium has a face-centered cubic structure with a melting point of $1555^{\circ} \mathrm{C}$. Even though it is believed that palladium has the highest vapor pressure of the platinum group metals, reliable data are not available. Compared with 
other metals, however, its vapor pressure is low. The thermal expansion of palladium is about $11.6 \times 10^{-6} /$ ${ }^{\circ} \mathrm{C}$, which is too low compared with that of the porcelains on the market $\left(14.0 \times 10^{-6 /{ }^{\circ}} \mathrm{C}\right)$. In order to raise the coefficient of thermal expansion of palladium and increase its strength, various metals such as gallium, tin, indium, copper, cobalt, and others are added. The solubility of these elements in one another is low, causing most silverless palladium alloys to have two phases. Phase diagrams of these elements clarify these points. The existence of two phases for porcelain-to-metal restorations is not an advantage, since one of the phases may have a lower melting temperature, which would soften during the baking of porcelain, causing distortion of the restorations. In general, having silver in the palladiumbased alloys increases the solubility of additive elements in the alloy and yields a single phase structure, but the presence of silver discolors the porcelain unless some precautions are observed. More work needs to be done in this area in order to have a single phase alloy, one with good castability and mechanical properties, to which porcelain could adhere without discoloration and produce sufficient bond strength. Also, more work in the porcelain area needs to be done in order to have a porcelain with good esthetics, easy application by dental technicians, stable coefficient of thermal expansion, and high bond strength with palladium alloys.

In the base metal area, the most promising metal is titanium. In 1977, Dr. Waterstrat (1977) started emphasizing that titanium alloys needed to be studied. Unfortunately, he did not receive the necessary financial support from granting agencies or moral support from his colleagues. Fortunately, he did not give up and continued to pursue his research interests. Today, suitability of titanium alloys has been established. It seems that research in the area of titanium alloys for dental usage should be encouraged in order to gain the ground lost during the past seven to eight years.

Probably the area that has been most ignored in the past by researchers is technique. The dental laboratories of today are facing great financial problems in obtaining the equipment necessary to fabricate appliances from newly developed materials. Consider the two ceramic materials that are on the market today. Each requires an oven and casting machine different from the ones used for casting metal appliances. This equipment is quite expensive. As a result, the small laboratories do not try to fabricate these materials, and the larger laboratories are hesitant as to whether they will be able to recover the cost before another material requiring yet a different set of equipment will be introduced. For this reason, dental laboratories are not easily persuaded to invest in new equipment and make dental appliances from newly developed ceramic materials. However, they are willing to try to use a newly developed alloy if they are convinced that it has better properties and if they do not have to invest in any new equipment.

It seems that future techniques should be powder techniques and not cast techniques. Theoretically, it can be visualized that dental laboratories would invest in a uniform burnout and sintering oven, which is capable of sintering any alloy or ceramic particle. A new die material needs to be developed on which the powder of an alloy or ceramic material can be pressed under isostatic pressure, and sintered at the proper temperature for that material. After necessary finishing, the restoration would be delivered to dental offices and finally to the patient. It seems that unless uniform equipment and techniques are available, it will be difficult for the benefit of newly developed materials to be passed on to the patients, which is the main goal of NIDR as well as of every researcher.

\section{APPENDIX}

Even though the emphasis in this paper is on the development of various alloys, porcelains, and investment materials from various manufacturers, this information could not have been gained without the research activities carried out at various institutes and support by the N.I.D.R. It would be impossible to cite all the papers published in this area by different individuals; however, they should not be completely ignored. Therefore, it was decided in the text of this paper to limit alphabetical citations of the directors of research at various centers, but to list some of their publications in the bibliography:

Anusavice and his co-workers at the University of Florida (Anusavice, 1985, 1986; Anusavice et al., 1982, 1983, 1985, 1986; Kaminski et al., 1985; Dehoff and Anusavice, 1985, 1986); Civjan, Huget, and Vermilyea and their colleagues at the Walter Reed Army Medical Center (Civjan et al., 1972, 1974, 1975, 1977; Huget et al., 1976, 1978 a,b; Vermilyea and Vilca, 1982; Townsend et al., 1983; Vermilyea et al., 1983); Fairhurst and his group at the Medical College of Georgia (Fairhurst, 1979, 1980, 1981; Ringle et al., 1977, 1978, 1981, 1982, 1983, 1986; Anusavice, 1980; Anusavice et al., 1977 a-c, 1979; Smith et al., 1980; Mackert et al., 1983, 1986; and Parry et al., 1986); Fusayama of Japan (1958 a,b, 1959, 1964; Fusayama and Yamane, 1973); Goodkind and his colleagues at the University of Minnesota (Lubovich and Goodkind, 1977; Rasmussen et al., 1979; De Long et al., 1982; Marker et al., 1986); Greener and his group at Northwestern University (Greener et al., 1986 a,b; Nakayama et al., 1984; Menis, 1986; Taira, 1986); U.S. Patents and publications of Clyde Ingersoll of the Williams Gold Company (1973, 1975 a-d, 1976, 1981, 1982; Ingersoll and Agarwal, 1978, 1983); McLean from England (1980, 1983; McLean and Sced, $1973 \mathrm{a}, \mathrm{b}$ ); Meyer and Nally at the University of Geneva, Switzerland (Nally and 
Meyer, 1969; Nally et al., 1968, 1972, 1979); Moffa at the U.S. Army Institute of Dental Research in San Francisco (1982; Moffa and Dent, 1982; Moffa and Watanabe, 1985; Moffa et al., 1973, 1984, 1986); Nielsen, Tuccillo, and Cascone at the Jelenko Company (Nielsen, 1978; Shell and Nielsen, 1962; Schulman and Nielsen, 1983; Tuccillo and Nielsen, 1964, 1967, 1968, 1971, 1972; Tuccillo, 1967, 1969, 1973; Tuccillo and Cascone, 1983; Cascone, 1979, 1983; Cascone and Nabatian, 1982; Cascone and Tuccillo, 1977; Cascone et al., 1978); O'Brien, Asgar, and co-workers at the University of Michigan (O'Brien, 1977; $O^{\prime}$ Brien and Ryge, 1964, 1965; Woolsey, 1984; Walton and O'Brien, 1985; Asgar and Arfaei, 1976; Asgar and Giday, 1978; Asgar et al., 1975, 1986; Cecconi and Asgar, 1975; Dootz and Asgar, 1986; Fuys et al., 1973, 1976 a,b; Lang et al., 1982; Nitkin and Asgar, 1976; Ogura et al., 1981; Rowe and Asgar, 1976; Rowe et al., 1974); Pask at the University of California at Berkeley (1980; Pask and Boron, 1966; Pask and Fulrath, 1962; Pask and Tomsia, 1985; Pask et al., 1985); Tesk at the National Bureau of Standards (1978; De Rijk and Tesk, 1986; Dudek and Tesk, 1977; Hinman and Tesk, 1985; Meiser et al., 1985; Natarajan et al., 1986; Tesk et al., 1981, 1983, 1985, 1986); and many others at different research centers, whose articles appear in the bibliography, and who have greatly contributed to the literature on dental castings.

\section{REFERENCES}

ADAIR, P.J. (1984): Glass-ceramic Dental Product, US Patent $4,431,420$.

AGARWAL, D.P.; INGERSOLL, C.E.; and SORENSON, S.E. (1978): Measurement of Coefficient of Thermal Expansion of a Ceramic Alloy, IADR Prog \& Abst 57: No. 726.

ANUSAVICE, K.J. (1985): Flexure Test Evaluation of Presoldered Base Metal Alloys, I Prosthet Dent 54: 507.

ANUSAVICE, K.J.; DEHOFF, P.H.; and FAIRHURST, C.W. (1980): Comparative Evaluation of Ceramic-Metal Bond Tests Using Finite Element Stress Analysis, y Dent Res 59: 608.

ANUSAVICE, K.J.; DEHOFF, P.H.; and LOCKWOOD, P.C. (1983): A Test Method for Measurement of Metal Ceramic System Distortion Effects, J Dent Res 62: 255.

ANUSAVICE, K.J.; DEHOFF, P.H.; GRAY, A; and LEE, R.B. (1986): Delayed Crack Propagation in Porcelain due to Incompatibility Stress, I Dent Res 65: 343.

ANUSAVICE, K.J. and HOJJATIE, B. (1986): Stress Distribution in Metal-Ceramic Crowns with a Facial Porcelain Margin, J Dent Res 65: 194.

ANUSAVICE, K.J.; RINGLE, R.D.; and FAIRHURST, C.W. (1977a): Adherence Controlling Elements in Ceramic-Metal Systems, Part 1, J Dent Res 56: 1045.

ANUSAVICE, K.J.; RINGLE, R.D.; and FAIRHURST, C.W. (1977b): Adherence Controlling Elements in Ceramic-Metal Systems, Part 2, I Dent Res 56: 1053.

ANUSAVICE, K.I.; RINGLE, R.D.; and FAIRHURST, C.W. (1977c): Bonding Mechanism Evidence in a Ceramic Non-precious Alloy System, I Bioned Mater Res 11: 701.

ANUSAVICE, K.J.; RINGLE, R.D.; and FAIRHURST, C.W. (1979): Identification of Fracture Zones in Porcelain-veneered-to-Metal Bond Test Specimens by ESCA Analysis, J Prosthet Dent 56: 1045. ANUSAVICE, K.J.; TWIGGS, S.W.; and DEHOFF, P.H. (1982):
Correlation of Thermal Shock Resistance with Thermal Compatibility for Metal-Porcelain Systems, J Dent Res 61: 419.

ASGAR, K. and ARFAEI, A.H. (1976): Testing of Bond Strain at the Porcelain-Metal Interface, IADR Prog $\&$ Abst 55: 508.

ASGAR, K.; DOOTZ, E.; and SHADMEHR, B. (1986): Physical Properties of 81 Alloys of Pd-Co-Ga-In System. In: Proceedings, Precious Metals 1985, E.D. Zysk and J.A. Bonucci, Eds., Allentown, PA: International Precious Metals Institute, pp. 311-331.

ASGAR, K. and GIDAY, Z. (1978): Refinements on Testing of Porcelain to Metal Bond, IADR Prog \& Abst 57: 870.

ASGAR, K.; HAMERINK, H.A.; and ARFAEI, A. (1975): A Pushshear Test for Porcelain to Metal Bond, IADR Prog \& Abst 54: 456 .

ASGAR, K.; MAHLER, D.B.; and PEYTON, F.A. (1954): The Behavior and Measurement of Hygroscopic Expansion of Dental Casting Investment, J Dent Res 33: 519.

ASGAR, K.; MAHLER, D.B.; and PEYTON, F.A (1955): Hygroscopic Technic for Inlay Casting Using Controlled Water Addition, J Prosthet Dent 5: 711 .

ASGAR, K.; MAHLER, D.B.; and PEYTON, F.A. (1958): Further Investigation into the Nature of Hygroscopic Expansion of Dental Casting Investment, I Prosthet Dent 8: 673.

ASGAR, K.; MORRIS, H.; and DOOTZ, E. (1982): Properties and Composition of Many Newly Developed Crown and Bridge Alloys, I Dent Res 61: 284.

BARAN, G. (1983a): Oxidation Kinetics of Some Ni-Cr Alloys, Dent Res 62: 51, Abst. No. 349.

BARAN, G. (1983b): Topography and Composition of Oxides on Ni-Cr Alloys, J Dent Res 62: 688.

BARAN, G. (1984a): Auger Chemical Analysis of Oxides on Ni-Cr Alloys, I Dent Res 63: 76.

BARAN, G. (1984b): Oxide Compounds on Ni-Cr Alloys, J Dent Res 63: 1332

BARAN, G. and WOODLAND, E.C. (1981a): Forming of Cast Precious Metal Alloys, J Dent Res 60: 1767.

BARAN, G. and WOODLAND, E.C. (1981b): Work Hardening and Forming Behavior of Cast Dental Allovs, I Biomed Mater Res 15: 835.

BARRETO, M.T.; GOLDBERG, A.J.; NITKIN, D.A.; and MUMFORD, G. (1980): Effect of Investment on Casting High-fusing Alloys, I Dent Res 44: 504.

BEALL, G.H. (1972): Mica Glass-ceramics, LS Pntent 3,689,293.

BERTOLOTTI, R.L. (1980): Calculation of Interfacial Stress on Porcelain-fused-to-Metal System, J Dent Res 59: 1972.

BERTOLOTTI, R.L. and FUKUI, H. (1982): Measurement of Softening Temperatures in Dental Bake-on Porcelain, / Dent Res 61 : 480 .

BERTOLOTTI, R.L. and SHELBY, J.E. (1979): Viscosity of Dental Porcelain as a Function of Temperature, ] Dent Res 58: 2001

BLANCO-DALMAU, L. (1983): Preventing Green Discoloration of Porcelain Baked Over Silver-Palladium Alloys, J Prosthet Dent 50: 865.

BOYAJIAN, B.K. (1981): Palladium Based Dental Alloy Containing Indium and Tin, US Patent 4,261,744.

BOYAJIAN, B.K. (1982): Palladium Based Dental Alloy Containing Indium and Tin, US Patent 4,319,877.

BROCKHURST, P.J.; MCLAVERTY, V.G.; and KASLOFF, Z. (1983): A Castability Standard for Alloys Used in Restorative Dentistry, Oper Dent 8: 130.

BURSE, A.B.; SWARTZ, M.L.; PHILLIPS, R.W.; and DYKEMA, R.W. (1972): Comparison of the in vitro and in vivo Tarnish of Three Gold Alloys, J Biomed Mater Res 6: 267.

CAPUTO, A.A.; DUNN, B.; and REISBICK, M.H. (1977): A Flexural Method for Evaluation of Metal-ceramic Bond Strengths, I Dent Res 56: 1501. 
CAPUTO, A.A. and MATYAS, J. (1983): New Generation High Palladium Casting Alloys, J Dent Res 62: 688, Abst. No. 344. CASCONE, P.J. (1978): Dental Alloy, US Patent 4,023,262.

CASCONE, P.J. (1979): Effect of Thermal Properties on Porcelainto-Metal Compatibility, IADR Prog \& Abst 58: No. 683.

CASCONE, P.J. (1983): Oxide Formation on Palladium Alloys and Its Effect on Porcelain Adherence, J Dent Res 62: 255.

CASCONE, P.J. (1985a): Low Gold Dental Alloy, US Patent 4,539,176.

CASCONE, P.J. (1985b): Non-staining Palladium Based Dental Alloys, US Patent 4,526,750.

CASCONE, P.J. ; MASSIMO, M.; and TUCCILLO, J.J. (1978): Theoretical Interfacial Reactions Responsible for Bonding in Porcelain-to-Metal Systems. Part II-Oxidation of Alloys, IADR Prog \& Abst 57: No. 872.

CASCONE, P.J. and NABATIAN, D. (1982): Determination of Thermal Expansion Compatibility Limits for Porcelain-Metal Systems, IADR Prog \& Abst 61: No. 1365.

CASCONE, P.J. and TUCCILLO, J.J. (1977): Theoretical Interfacial Reactions Responsible for Bonding in Porcelain-to-Metal Systems, AADR Prog \& Abst 56: No. 640.

CECCONI, B.T. and ASGAR, K. (1975): Modified Hygroscopic Gold Casting Technique, J Prosthet Dent 33: 216.

CIVJAN, S.; HUGET, E.F.; De SIMON, L.B.; and RISINGER, R.J. (1974): Determination of Apparent Bond Strength of Alloy-Porcelain Systems, IADR Prog \& Abst 53: No. 742.

CIVJAN, S.; HUGET, E.F.; DVIVEDI, N.; and COSNER, H.J., Jr. (1975): Further Studies on Gold Alloys used in Fabrication of Porcelain-fused-to-Metal Restorations, J Am Dent Assoc 90: 659.

CIVJAN, S.; HUGET, E.F.; and MARSDEN, J.E. (1972): Characteristics of Two Gold Alloys used in Fabrication of Porcelainfused-to-Metal Restorations, J Am Dent Assoc 85: 1309.

COLEMAN, R.L. and WEINSTEIN, L.J. (1933): Investment, US Patent 1,932,202.

COY, H.D. (1933): An Application of Recent Developments in Inlay Castings, I Am Dent Assoc 20: 212.

CRAWFORD, W.H. (1940): Selection and Use of Investment Sprue in Making Small Castings, I Am Dent Assoc 27: 1459.

De RIJK, W.G. and TESK, J.A. (1986): The Distribution of Failure Stresses in Porcelain to Metal System, J Dent Res 65: 217, Abst. No. 431.

DEGNI, F. (1946): The Hygroscopic Expansion of Dental Investment, Thesis, Northwestern Univ Dent Sch.

DEHOFF, P.H. and ANUSAVICE, K.J. (1985): Analysis of AlloyPorcelain Compatibility Using a Multicomponent Material Strip Equation, J Dent Res 64: 1337.

DEHOFF, P.H. and ANUSAVICE, K.J. (1986): Influence of Geometry on Incompatibility in Metal-Ceramic Systems, J Dent Res 65: 217.

DELGADO, V.P. and PEYTON, F.A. (1953): The Hygroscopic Setting Expansion of Dental Casting Investment, J Prosthet Dent 3: 423.

DELONG, R.; DOUGLAS, W.H.; and GOODKIND, R.J. (1982): Corrosion-fatigue of the Bond Between Nickel-chrome Casting Alloys and Porcelain, J Prosthet Dent 52: 344.

DICKSON, G.; LYON, H.W.; and SCHOONOVER, I.C. (1955): The Mechanism of Hygroscopic Expansion in Dental Castings, J Dent Res 34: 44.

DOCKING, A.R.; CHONG, M.P.; and DONNISON, J.A. (1948a): Hygroscopic Setting Expansion of Dental Casting Investments, Aust Dent J 52: 6.

DOCKING, A.R.; CHONG, M.P.; and DONNISON, J.A. (1948b): Hygroscopic Setting Expansion of Dental Casting Investments, Aust Dent J 52: 160.

DOCKING, A.R.; CHONG, M.P.; and DONNISON, J.A. (1948c): Hygroscopic Setting Expansion of Dental Casting Investments, Aust Dent J 52: 320.
DOCKING, A.R.; CHONG, M.P.; and DONNISON, J.A. (1949): Hygroscopic Setting Expansion of Dental Casting Investments, Aust Dent J 53: 261.

DOOTZ, E.R. and ASGAR, K. (1986): Solidification Patterns of Single Crowns and Three-unit Bridge Castings, Quintessence Dent Tech 10: 299.

DOOTZ, E.R.; CRAIG, R.G.; and PEYTON, F.A. (1966): A New "Shell Casting" Technic, Dent Lab Rev, July.

DUDEK, R.P. and TESK, J.A. (1977): Evaluation of Alternative Alloys to Type III Gold for Use in Fixed Prosthodontics Critical of Techniques, J Am Dent Assoc 94: 24.

EDEN, G.T.; FRANKLIN, O.M.; POWER, H.M.; OHTA, Y.; and DICKSON, G. (1979): Fit of Porcelain Fused-to-Metal Crown and Bridge Castings, J Dent Res 58: 2360.

FAIRHURST, C.W.; ANUSAVICE, K.J.; HASHINGER, D.T.; RINGLE, R.D.; and TWIGGS, S.W. (1980): Thermal Expansion of Dental Alloys and Porcelains, J Biomed Mater Res 14: 435.

FAIRHURST, C.W.; ANUSAVICE, K.J.; RINGLE, R.D.; and TWIGGS, S.W. (1981): Porcelain-Metal Thermal Compatibility, J Dent Res 60: 815.

FAIRHURST, C.W.; RINGLE, R.D.; and ANUSAVICE, K.J. (1979): Microstructures in Nonprecious Alloys Near the Porcelain-Metal Interaction Zone, J Dent Res 58: 1987.

FAUCHER, R.R. and NICHOLLS, J.I. (1980): Distortion Related to Margin Design in Porcelain-fused-to-Metal Restorations, J Prosthet Dent 43: 149.

FUSAYAMA, T. (1957): Proposition of Theory on the Mechanism of Hygroscopic Expansion of Gypsum Products, Bull Tokyo Med Dent Univ 4: 225.

FUSAYAMA, T. (1958a): Factors and Techniques of Precision Casting, Part 1, J Prosthet Dent 9: 468.

FUSAYAMA, T. (1958b): Factors and Techniques of Precision Casting, Part 2, J Prosthet Dent 9: 486.

FUSAYAMA, T. (1959): Technical Procedure of Precision Casting, J Prosthet Dent 9: 1037.

FUSAYAMA, T. (1964): Synthetic Study on Precision Dental Casting, Bull Tokyo Med Dent Univ 11: 165.

FUSAYAMA, T. and YAMANE, M. (1973): Surface Roughness of Castings Made by Various Casting Techniques, I Prosthet Dent 19: 529 .

FUYS, R.A., Jr.; CRAIG, R.G.; and ASGAR, K. (1976a): Characterization of Porosity of Isostatically Pressed and Sintered Nickelbase Powdered Metal, J Oral Rehabil 3: 217.

FUYS, R.A., Jr.; CRAIG, R.G.; and ASGAR, K. (1976b): Physical Properties of a Nickel-base Alloy Prepared by Isostatic Pressing and Sintering of the Powdered Metal, J Oral Rehabil 3: 151.

FUYS, R.A.; FAIRHURST, C.W.; and O'BRIEN, W.J. (1973): Precipitation Hardening in Gold-Platinum Alloys Containing Small Quantities of Iron, J Biomed Mater Res 7: 471.

GREENER, E.H.; MOSER, J.B.; OPP, J.; SZURGOT, K.; and MARKER, B.C. (1986a): Dental Castability of Ti and Ti-6A1-4V, J Dent Res 65: 301, Abst. No. 1190.

GREENER, E.H.; MOSER, J.B.; OPP, J.; SZURGOT, K.; and MARKER, B.C. (1986b): Properties of Centrifugally Cast Commercial Ti and Ti-6A1-4V, J Dent Res 65: 317, Abst. No. 1329.

GROSSMAN, D.G. (1973): Tetrasilicic Mica Glass-ceramic Method, US Patent $3,732,087$.

HINMAN, R.W. and TESK, J.A. (1985): Improving the Casting Accuracy of Fixed Partial Dentures, J Prosthet Dent 53: 466.

HOLLENBACK, G.M. (1943): Precision Gold Inlays Made by a Simple Technic, J Am Dent Assoc 30: 99.

HOLLENBACK, G.M. (1948): Simple Technic for Accurate Castings: New and Original Method of Vacuum Investing, I Am Dent Assoc 36: 391.

HUGET, E.F.; DVIVEDI, N.; and COSNER, H.E., Jr. (1976): Char- 
acterization of Gold-Palladium-Silver and Palladium-Silver for Ceramic-Metal Restorations, J Prosthet Dent 36: 58.

HUGET, E.F.; DVIVEDI, N.; and COSNER, H.E., Jr. (1977): Properties of Two Nickel-Chromium Crown-and-Bridge Alloys for Porcelain Veneering, I Am Dent Assoc 94: 87.

HUGET, E.F.; VERMILYEA, S.G.; and VILCA, J.M. (1978a): Studies on White Crown-and-Bridge Alloys, IADR Prog E Abst 57: No. 722.

HUGET, E.F.; VILCA, J.M.; and WALL, R.M. (1978b): Characterization of Two Ceramic-Base-Metal Alloys, J Prosthet Dent 40: 637.

INGERSOLL, C.E. (1973): Bright Cast Alloy and Composition, US Patent 3,769,006.

INGERSOLL, C.E. (1975a): Tarnish Resistant Palladium Base Dental Casting Alloy, US Patent 3,929,474.

INGERSOLL, C.E. (1975b): Ceramic Substrate Alloy, US Patent $4,201,577$

INGERSOLL, C.E. (1975c): Method of Investment Casting a Bright Gold Alloy, US Patent 3,861,455.

INGERSOLL, C.E. (1975d): Tarnish Resistant Silver Base Dental Casting Alloy Having Superior Improved Ductility and Work Hardening Characteristics, US Patent 3,929,495.

INGERSOLL, C.E. (1976): Characterization of Tarnish, IADR Prog \& Abst 55: No. 144. [Also, Dent. Mat. Gp. microfilm, 1976.]

INGERSOLL, C.E. (1981): Ceramic Substrate Alloy, US Patent $4,249,943$

INGERSOLL, C.E. (1982): A Porcelain Fused to Metal Technic, IADR Prog \& Abst 61: No. 1504.

INGERSOLL, C.E. and AGARWAL, D.P. (1983): High Temperature Brazing Alloy, US Patent 4,399,096.

JOCHEN, D.G.; CAPUTO, A.A.; and MATYAS, J. (1985): Reuse of Silver Palladium Ceramic Metal, J Dent Res 64: 227, Abst. No. 472 .

JØRGENSEN, K.D. (1956): Studies on the Setting of Plaster of Paris, Scand J Dent Res 35: 499.

KAMINSKI, R.A.; ANUSAVICE, K.J.; OKABE, T.; MORSE, P.K.; and CASTEEL, P.E. (1985): Castability of Silver-base Fixed Partial Denture Alloys, I Prosthet Dent 53: 329.

KELLY, G.P. (1970): Study of Porosity and Voids in Dental Gold Castings, J Dent Res 49: 986.

KELLY, M. and ASGAR, K. (1969): Tensile Strength Determination of the Interface Between Porcelain Fused to Gold, J Biomed Mater Res 3: 403.

KLSY, R.P. and LEINFELDER, K.F. (1981): Age-hardening and Tensile Properties of Low Gold Alloys, J Biomed Mater Res 15: 117.

LANDGREN, N. and PEYTON, F.A. (1950): Hygroscopic Expansion of Some Casting Investments, J Dent Res 29: 469.

LANG, B.R.; BERNIER, S.H.; GIDAY, Z.; and ASGAR, K. (1982): Tarnish and Corrosion of Noble Metal Alloys, J Prosthet Dent 48 245.

LASATER, R.L. (1940): Control of Wax Distortion by Manipulation, I Am Dent Assoc 27: 518.

LEINFELDER, K.F.; O'BRIEN, W.J.; RYGE, G.; and FAIRHURST, C.W. (1966): Hardening of High-fusing Gold Alloys, I Dent Res 45: 392 .

LEINFELDER, K.F.; SERVAIS, W.J.; and O'BRIEN, W.J. (1969): Mechanical Properties of High-fusing Gold Alloys, J Prosthet Dent 21: 523 .

LEINFELDER, K.F. and TAYLOR, D.F. (1977): Hardening of GoldBase Alloys, J Dent Res 56: 335.

LLBOVICH, R.P. and GOODKIND, R.J. (1977): Bond Strength Studies of Precious, Semiprecious, and Nonprecious Ceramicmetal Alloys With Two Porcelains, I Prosthet Dent 37: 288.

MACKERT, J.R., Jr.; RINGLE, R.D.; and FAIRHURST, C.W. (1983):
High Temperature Behavior of a Pd-Ag Alloy for Porcelain, J Dent Res 62: 1229.

MACKERT, J.R., Jr.; RINGLE, R.D.; PARRY, E.E.; EVANS, A.L.; and FAIRHURST, C.W. (1986): A Constant-strain Flexure Apparatus Evaluating the Porcelain-metal Bond, 7 Dent Res 65: 218, Abst. No. 438.

MAHLER, D.B. and ADY, B.A. (1960): An Explanation for the Hygroscopic Setting Expansion of Dental Gypsum Products, I Dent Res 39: 578.

MARKER, J.C.; GOODKIND, R.J.; and GERBERICH, W.W. (1986): The Compressive Strength of Nonprecious Versus Precious Ceramometal Restorations With Various Frame Designs, I Prosthet Dent 55: 560 .

MARTIN, O. (1891): (No title), Dent Item Int 12: 575.

MAVES, T.W. (1932): Recent Experiments Demonstrating Wax Distortion on All Wax Patterns When Heat is Applied, I Am Dent Assoc 19: 606 .

McLEAN, J.W., Ed. (1979): The Science and Art of Dental Ceramics, Vol. I, Chicago: Quintessence Publishing.

McLEAN, J.W., Ed. (1980): The Science and Art of Dental Ceramics, Vol. II, Chicago: Quintessence Publishing.

McLEAN, J.W., Ed. (1983): Dental Ceramics, Proceedings, First International Symposium on Ceramics, Chicago: Quintessence Publishing.

McLEAN, J.W. and SCED, I.R. (1973a): Bonding of Dental Porcelain to Metal, Trans Br Ceram Soc 72: 235.

McLEAN, J.W. and SCED, I.R. (1973b): The Gold Alloy/Porcelain Bond, Trans Br Ceram Soc 72: 233.

MEISER, E.T.; DeRIJK, W.G.; and TESK, J.A. (1985): Internal Setting Expansion of Dental Casting Investment Measured with Strain Gauges, J Prosthet Dent 53: 870.

MENIS, D.L.; MOSER, J.B.; and GREENER, E.H. (1986): Experimental Porcelain Compositions for Application to Cast Titanium, J Dent Res 65: 343, Abst. No. 1565.

MOFFA, J.P. (1982): Biological Effects of Nickel-containing Dental Alloys, J Am Dent Assoc 104: 501.

MOFFA, J.P. and DENT, R.J. (1982): Effect of Oxidation on Ceramometal Bond Strength, J Prosthet Dent 47: 59.

MOFFA, J.P.; fENKINS, W.A.; and ELLISON, J.A. (1984): A Clinical Evaluation of Two Base Metal Alloys and Gold Alloy for Use in Fixed Prosthodontics. A Five Year Study, I Prosthet Dent 52: 491.

MOFFA, J.P.; LUGASSY, A.A.; GUCKES, A.D.; and GETTLEMAN, L. (1973): An Evaluation of Nonprecious Alloys for Use with Porcelain Veneers. Part I. Physical Properties, I Prosthet Dent 30: 424

MOHAMMED, H. and ASGAR, K. (1973a): A New Dental Superalloy System. Part I, Theory and Alloy Design, I Dent Res 52: 136.

MOHAMMED, H. and ASGAR, K. (1973b): A New Dental Superalloy System. Part II, Mechanical Properties, J Dent Res 52: 145.

MOHAMMED, H. and ASGAR, K. (1973c): A New Dental Superalloy System. Part III, Microstructure and Phase Transformations, I Dent Res 52: 151.

MOSER, J.B.; LIN, J.-H.; TAIRA, M.; and GREENER, E.H. (1984): Corrosion and Microhardness of $\mathrm{Cu}-\mathrm{Ti}$ and Co-Ti Systems, I Dent Res 63: 259.

NAKAYAMA, M.; MOSER, J.B.; and GREENER, E.H. (1984): Corrosion and Tarnish of Aluminum Bronze, Dent Mat J 3: 133.

NALLY, J.-N. and MEYER, J.-M. (1969): Electron Microprobe Investigations on the Ceramic-to-gold Interface to Explain the Nature of the Chemical Bonding, IADR Prog \& Abst 48: No. 592.

NALLY, J.-N.; MEYER, J.-M.; and GOELLER, I. (1972): Comparative Study of Three Coating Agents and Their Influence on Bond Strength of Porcelain to Gold Alloys, I Prosthet Dent 28: 504 . 
NALLY, J.N.; MEYER, J.M.; and PAYAN, J. (1979): Evaluation of Alternative Alloys to Precious Ceramic Alloys. I. Mechanical Properties, J Oral Rehabil 6: 291.

NALLY, J.-N.; MONNIER, D.; and MEYER, J.-M. (1968): Distribution Topographique de Certain Elements de L'alliage et de la Porcelain au Niveau de la Liaison Ceramo-Metallique, Schweiz Monats fuer Zahn 78: 868.

NATARAJAN, R.; WIDERA, G.E.O.; MIN, B.J.; and TESK, J.A. (1986): Residual Stress Distribution in Metallic Ceramic Crowns, $J$ Dent Res 65: 343, Abst. No. 1566.

NIELSEN, J.P. (1978): Pressure Distribution in Centrifugal Dental Casting, J Dent Res 57: 261.

NIELSEN, J.P. and SHALITA, S. (1977): Margin Casting Monitor, IADR Prog \& Abst 56: No. 645.

NIELSEN, J.P. and TUCCILLO, J.J. (1966): Grain Size in Cast Gold Alloys, J Dent Res 45: 964.

NIELSEN, J.P. and TUCCILLO, J.J. (1969): Microprobe Analysis of the Porcelain-Gold Interface, IADR Prog \& Abst 48: No. 594.

NIELSEN, J.P. and TUCCILLO, J.J. (1971): Interfacial Stress Measurements in Bonded Porcelain-Gold Alloy Systems, IADR Prog E Abst 49: No. 315.

NITKIN, D.A. and ASGAR, K. (1976): Evaluation of Alternative Alloys to Type III Gold for Use in Fixed Prosthodontics, J Am Dent Assoc 93: 622

O'BRIEN, W.J. (1977): The Cohesive Plateau Stress of Ceramicmetal Systems, IADR Prog \& Abst 56: No. 501.

O'BRIEN, W.J.; KRING, J.E.; and RYGE, G. (1964): Heat Treatment of Alloys to Be Used for the Fused Porcelain Technique, J Prosthet Dent 14: 955.

O'BRIEN, W.J. and RYGE, G. (1965): Contact Angles of Drops of Enamels on Metals, J Prosthet Dent 15: 1094.

OGURA, H.; RAPTIS, C.N.; and ASGAR, K. (1981): Inner Surface Roughness of Complete Cast Crowns Made by Centrifugal Casting Machines, J Prosthet Dent 45: 529.

PARRY, E.E.; MACKERT, J.R., Jr.; RINGLE, R.D.; EVANS, A.L.; and FAIRHURST, C.W. (1986): Improvement of Oxide Adherence to a Ni-Cr-Mo Ternary Alloy by Active Element Additions, J Dent Res 65: 218, Abst. No. 437.

PASK, J.A., Ed. (1980): Modern Aspects of the Vitreous State, Vol. 3 , London:Butterworths.

PASK, J.A. and BOROM, M.P. (1966): The Role of Adherence Oxides in the Role of Chemical Bonding at Glass-Metal Interfaces, J Am Ceram Soc 49: 1.

PASK, J.A. and FULRATH, R.M. (1962): Fundamentals of Glassto-Metal Bonding, I Am Ceram Soc 45: 592.

PASK, J.A. and TOMSIA, A.P. (1985): Oxidation and Ceramic Coatings on Ni80Cr20 Alloy, J Dent Res 64: 227, Abst. No. 475.

PASK, J.A.; TOMSIA, A.P.; and MARSHALL, D.B. (1985): An Indentation Technique for Measuring Adherence at Glass/metal Interfaces, I Dent Res 64: 227, Abst. No. 476.

PHILBROOK, B.F. (1896-97): Cast Fillings, Trans Iowa State Dent Soc, p. 277.

PHILLIPS, D.W. (1933): A Scientifically Correct Inlay Technique, Dent Dig 39: 72

PRASAD, A. (1983a): Hot Tears vs. No Tears, Dent Lab Rev 58: 34.

PRASAD, A. (1983b): Palladium Based Dental Alloys, US Patent $4,412,970$.

PRASAD, A. (1984): Dental Alloys for Porcelain-fused-to-Metal Restorations, US Patent 4,451,639.

PRASAD, A. (1985a): Dental Alloy for Porcelain-fused-to-Metal Restorations, US Patent 4,539,177.

PRASAD, A. (1985b): Gallium and Silver Free Palladium Based Dental Alloy for Porcelain-fused-to-Metal Restoration, US Patent $4,518,564$.

RASMUSSEN, E.J.; GOODKIND, R.J.; and GERBERICH, W.W.
(1979): An Investigation of Tensile Strength of Dental Solder, I Prosthet Dent 41: 418.

RINGLE, R.D.; FAIRHURST, C.W.; and ANUSAVICE, K.J. (1977): The Microstructure of Ni-Cr Alloys for Porcelain Fused to Metal Systems, Third Annual Meeting Soc for Biomat, Abstr. No. 1.

RINGLE, R.D.; MACKERT, J.R., Jr.; and FAIRHURST, C.W. (1981): Oxidation Characteristics of Pd-Ag-Sn Alloys, IADR Prog $\mathcal{E}$ Abst 60: No. 832. [Also, Dent. Mat. Gp. microfilm, 1981.]

RINGLE, R.D.; MACKERT, J.R., Jr.; and FAIRHURST, C.W. (1982): Use of Metallographic and EXDS Technique to Measure Adherent Porcelain, IADR Prog \& Abst 61: No. 947.

RINGLE, R.D.; MACKERT, J.R., Jr.; and FAIRHURST, C.W. (1983): An X-ray Spectrometric Technique for Measuring Porcelain-Metal Adherence, J Dent Res 62: 933.

RINGLE, R.D.; MACKERT, J.R., Jr.; and FAIRHURST, C.W. (1986): Prevention of Porcelain Greening by External Oxidation in a PdAg-Mn-Al Dental Alloy System, J Dent Res 65: 218, Abst. No. 436.

RINGLE, R.D.; WEBER, R.L.; ANUSAVICE, K.J.; and FAIRHURST, C.W. (1978): Thermal Expansion/contraction Behavior of Dental Porcelain-Alloy Systems, IADR Prog \& Abst 57: No. 877.

ROWE, A.P. and ASGAR, K. (1976): Thermal Study of Porcelain Substrate Metals, IADR Prog \& Abst 55: 505.

ROWE, A.P.; BIGELOW, W.C.; and ASGAR, K. (1974): Effect of Tantalum Additions to a Cobalt-chromium-nickel Base Alloy, J Dent Res 53: 325.

RUPP, N.W. (1985): Personal communication.

RUPP, N.W. (1986): Personal communication.

RYGE, G. and FAIRHURST, C.W. (1956): Hygroscopic Expansion, J Dent Res 35: 499.

SCHAFFER, S.P. (1983): Novel Palladium Alloy and Dental Restorations Utilizing Same, US Patent 4,387,072.

SCHEU, C.H. (1932): A New Precision Casting Technique, J Am Dent Assoc 19: 630.

SCHEU, C.H. (1933): Precision Casting Utilizing Hygroscopic Action of Plaster in Investment in Making Expanded Mold, J Am Dent Assoc 20: 1205.

SCHULMAN, A. and NIELSEN, J.P. (1983): New Dental Casting Alloy, $N$ Y State Dent J 49: 562.

SHAN-SHIH, K.; VAIDYANATHAN, T.K.; and VAIDYANATHAN, J. (1983): Chloride Corrosion of Ni-Pd Alloys, J Dent Res 62: 688, Abst. No. 345.

SHELL, J.S. and NIELSEN, J.P. (1962): Study of the Bond Between Gold Alloys and Porcelain, J Dent Res 41: 1424.

SKINNER, E.W. and DEGNI, F. (1957): Hygroscopic Expansion of Dental Investments, J Am Dent Assoc 54: 604.

SLOAN, R.M.; REISBICK, M.H.; and PRESTON, J.D. (1982): Postceramic Soldering of Various Alloys, J Prosthet Dent 48: 686.

SMITH, C.D.; DECKMAN, J.; and FAIRHURST, C.W. (1980): An Alloy Castability and Adaptation Test, IADR Prog \& Abst 59: No. 328

SMYD, E.S. (1948): Factors which Influence Casting Accuracy: A Universal Casting Technic, J Am Dent Assoc 36: 160.

SOZIO, R.B. (1986): Dental Appliance and Method of Manufacture, US Patent 4,585,417.

STAFFANOU, R.S.; RADKE, R.A.; and JENDRESEN, M.D. (1980): Strength Properties of Soldered Joints from Various CeramicMetal Combinations, J Prosthet Dent 43: 31.

STURDEVANT, C.M. and STRICKLAND, W.D. (1959): Porosity in the Full Cast Crown, I Am Dent Assoc 58: 69.

SUMITRA, N.; VAIDYANATHAN, T.K.; SASTRI, S.; and PRASAD, A. (1983): Chloride Corrosion of Recent Commercial Pdbase Alloys, I Dent Res 62: 688, Abst. No. 346.

SWAYSEY, A.J. (1890): Proceedings of the Thirteenth Annual Meeting of the American Dental Association, Dent Regis 44: 501. 
SWEENEY, W.T. (1933): Cristobalite for Dental Investments, J Am Dent Assoc 20: 108.

TAGGART, W.H. (1907): A New and Accurate Method of Making Gold Inlays, Dent Cosmos 49: 1117.

TAIRA, M.; MOSER, J.B.; and GREENER, E.H. (1985): Face Coat for Dental Casting of Titanium Alloys, J Dent Res 64: 317.

TAIRA, M.; MOSER, J.B.; and GREENER, E.H. (1986): Mechanical Properties of Cast Ti Alloys for Dental Usage, I Dent Res 65: 236, Abst. No. 603.

TESK, J.A. (1978): Effects of Alloying Additions on the Color of Gold Alloys, IADR Prog \& Abst 57: No. 720.

TESK, J.A.; HINMAN, R.W.; and WHITLOCK, R.P. (1985): A Technique for Characterizing Casting Behavior of Dental Alloys, J Dent Res 65: 147.

TESK, J.A.; HINMAN, R.W.; and WIDERA, G.E. (1983): Effect of Porcelain/Alloy Interfacial Diffusion Zones on Thermomechanical Strain, J Dent Res 62: 585.

TESK, J.A.; OKUNO, O.; and PENN, R. (1986): Mesh Monitor Casting of Ni-Cr Alloys: Element Effect, I Dent Res 65: 301, Abst. No. 1187.

TOWNSEND, L.W.A.; VERMILYEA, S.G.; and GRISWOLD, W.H. (1983): Soldering Nonnoble Alloys, J Prosthet Dent 50: 51.

TUCCILLO, J.J. (1967): Dental Gold Alloys, US Patent 3,340,050.

TUCCILLO, J.J. (1969): Metal Alloy Composition, US Patent $3,424,577$.

TUCCILLO, J.J. (1973): Tarnish Resistant Alloy, US Patent 3,767,391.

TUCCILLO, J.J. (1976a): Dental Restorations Combining Dental Porcelain and Improved White Gold Alloy, US Patent 3,961,420.

TUCCILlO, J.J. (1976b): Dental Restorations Combining Dental Porcelain and Improved White Gold Alloy, US Patent 3,981,723.

TUCCILLO, J.J. and CASCONE, P.J. (1983): The Evaluation of Porcelain to Metal System. In: Proceedings, First National Symposium on Ceramics, J.W. McLean, Ed., Chicago: Quintessence Publishing, pp. 347-370.

TUCCILLO, J.J. and NIELSEN, J.P. (1964a): Review of Sprue Design for Cast Gold Alloys, Dent Lab Rev 39: June-July.

TUCCILLO, J.J. and NIELSEN, J.P. (1964b): Sprue Design for Cast Gold Alloys, Dent Lab Rev 39: 14.

TUCCILLO, J.J. and NIELSEN, J.P. (1967): Creep and Sag Properties of Porcelain-Gold Alloys, J Dent Res 46: 579.

TUCCILLO, J.J. and NIELSEN, J.P. (1968): Thermal and Reaction Effects in Porcelain-Metal Restorations, IADR Prog \& Abst 47: 118, Abst. No. 324.
TUCCILLO, J.J. and NIELSEN, J.P. (1971): Observations of Onset of Sulfide Tarnish on Gold-base Alloys, I Prosthet Dent 25: 269.

TUCCILLO, J.J. and NIELSEN, J.P. (1972): Shear Stress Measurements at a Dental Porcelain-Gold Bond Interface, J Dent Res 51: 626 .

VAIDYANATHAN, T.K. and PRASAD, A. (1981a): In vitro Corrosion and Tarnish Characterization of Typical Dental Gold Compositions, J Biomed Mater Res 15: 191.

VAIDYANATHAN, T.K. and PRASAD, A. (1981b): In vivo Corrosion and Tarnish Analysis of Ag-Pd Binary System, I Dent Res 60: 707

VAIDYANATHAN, T.K.; SCHULMAN, A.; NIELSEN, J.P.; and SHALITA, S. (1981): Correlation Between Microscopic Porosity Location and Liquid Metal Pressure in Centrifugal Casting Technique, I Dent Res 60: 59 .

VAN HORN, W.H. (1907): Casting: A Review and Commentary including a Technique, Dent Cosmos 52: 873.

VERMILYEA, S.G.; KUFFLER, M.J.; and TAMURA, J.J. (1983) Casting Accuracy of Base Metal Alloys, I Prosthet Dent 50: 651.

VERMILYEA, S.G. and VILCA, J.M. (1982): Low Gold Fixed Prosthodontic Alloys, I Prosthet Dent 48: 159.

VOLLAND, R.H. and PAFFENBARGER, G.C. (1932): Cast Gold Inlay Technique as Worked Out in the Cooperative Research at the National Bureau of Standards Applied by a Group of Practicing Dentists, I Am Dent Assoc 19: 185.

WALTON, T.R. and O'BRIEN, W.J. (1985): Thermal Stress Failure of Porcelain Bonded to a Palladium-Silver Alloy, J Dent Res 64: 476.

WATERSTRAT, R.M. (1977): In: Proceedings, Alternatives to Gold Alloys in Dentistry, T.M. Valega, Ed., Bethesda, MD: DHEW Publ. No. (NIH) 77-1227, pp. 225-233.

WATERSTRAT, R.M. and GIUSEPPETTI, A.A. (1985): Casting Apparatus and Investment Mold Materials for Metals Which Melt at Very High Temperatures, J Dent Res 64: 317.

WEINSTEIN, M.; KATZ, S.; and WEINSTEIN, A.B. (1962a): Fused Porcelain to Metal Teeth, US Patent 3,052,982.

WEINSTEIN, M.; KATZ, S.; and WEINSTEIN, A.B. (1962b): Porcelain Covered Metal Reinforced Teeth, US Patent 3,052,983.

WHITLOCK, R.P.; HINMAN, R.W.; EDEN, G.T.; TESK, J.A.; DICKSON, G.; and PARRY, E.E. (1981): A Practical Test to Evaluate the Castability of Dental Alloys, IADR Prog \& Abst 60: 376.

WOOLSEY, G.D.; JOHNSTON, W.M.; and O'BRIEN, W.J. (1984): Masking Power of Dental Opaque Porcelains, J Dent Res 63: 936. 